\title{
Microbiome and Antimicrobial Resistance in Members of the Enterobacteriaceae Family from Vaginal and Preputial Mucous Isolates of Stray Dogs
}

\author{
Laisa Marina Rosa Rey, Carlos Renato de Freitas Guaitolini, Kawany Gabrieli Zanetti Fazoli, \\ Lucas Lima da Silva, Túlio Tozzi Fendrigo, Isabela Carvalho dos Santos, Melissa Marchi Zaniolo, \\ Lisiane de Almeida Martins \& Daniela Dib Gonçalves
}

\begin{abstract}
Background: Contact between humans and pets, mainly dogs and cats, has been increasing in recent years, which may result in the spread of infectious agents to new hosts and even to the environment, causing emergencies of national and international interest. The aim of this work was to understand the phenotypic profile of bacteria of the Enterobacteriaceae family of vaginal and preputial mucous of stray dogs from a border region.

Materials, Methods \& Results: Swab samples from the vaginal and preputial mucosa of stray dogs from two border regions were collected for later bacterial isolation, biochemical identification of bacterial isolates, susceptibility tests to different antimicrobials, and determination of the bacterial resistance index. Samples were collected from 70 animals, was possible to isolate 88 samples, of which $36(40.9 \%)$ presented isolates of Gram-negative bacteria, with Escherichia coli being the most prevalent species (44.8\%), followed by Obesumbacterium proteus in eight (27.5\%); Enterobacter aerogenes and Enterobacter cloacae in two (6.8\%); and Erwinia herbicola, Koserella trabulsii, Proteus mirabilis, and Serratia rubidaea (3.4\%) from one isolate. The most resistant antimicrobials Clindamycin (100\%), Metronidazole (100\%), Oxacillin (100\%), and Penicillin (100\%) were tested against the vaginal and preputial samples and when the multidrug resistance index of the isolates was analyzed, all were classified as presenting a public health risk.

Discussion: The results of this work suggest that stray dogs may be considered potential reservoirs of resistant pathogenic microorganisms, enabling future health problems due to the close coexistence of tutors with their dogs. It is known that the microorganisms that inhabit a certain environment or a specific part of the body are collectively called microbiomes. More specifically, some of them are bacteria that inhabit the reproductive mucous membranes (vaginal and preputial) of healthy dogs. Several works have also identified $E$. coli as the most prevalent bacteria identified in the vaginal and preputial mucosa of healthy dogs, that is regarded as a member of different microbiomes that is a commensal of different species of domestic animals, it is important to stress that this bacterial species presents sophisticated virulence mechanisms possibly responsible for different nosocomial infections as well as community infections in mankind and different species of animals. Found other bacterial species suggests a connection of these bacterial species with different environments and different animal species, which is even more disturbing regarding public health, since most of the time dogs share the same spaces of their tutors, which would facilitate the transmission and interaction with potentially pathogenic microorganisms. The MAR index result is worrying when dealing with stray and asymptomatic dogs, since the behavioral particularities of canine species such as licking the body, licking the genitalia, sniffing the environment for territorial demarcation and, in some cases, coprophagy, may facilitate the transmission of pathogenic microorganisms and even disseminate genes of resistance to their keepers, other animals, and even to the environment. Unique health education works should be conducted in border regions in order to raise awareness of the population involved about the different situations that may favor the dissemination of microorganisms and their resistance genes, including the problems caused by the illegal sale and/or transportation of drugs, a situation that is very common in borders.
\end{abstract}

Keywords: antibiotics, reproductive mucosae, enterobacteria, Unique Health, border region.

DOI: $10.22456 / 1679-9216.104699$

Accepted: 8 November 2020

Published: 9 December 2020 


\section{INTRODUCTION}

Many terms are attributed to borders and according to author [1], they may be recognized as a problem, limit, or even as a life opportunity. For this reason the epidemiological and health surveillance in border regions are of extreme importance for detecting potential pathogens.

Contact between humans and pets, especially dogs and cats, has been increasing in recent years, which may lead to the spread of infectious agents to new hosts and even to the environment, causing emergencies of national and international interest [2].

The term microbiome refers to the population of microorganisms that inhabit a certain part of the body, like the skin and mucous membranes [4]. The vaginal microbiota represents one of the most important defense mechanisms of the reproductive system [5]. In males, the literature is scarce about the recording of descriptive and/or epidemiological data. However, it is well known that the relationship between the host and microorganisms might influence the metabolism, development, and immunological status of the animal [6].

Bacterial resistance is currently a serious problem worldwide [7]. This is due to the indiscriminate use of antimicrobials, the application of inadequate doses, and other irregularities regarding the use of these drugs [8]. Monitoring antimicrobial resistance is important since these animals live in the same environment as their tutors and in most cases they both share the same space $[9,10]$. Therefore, the objective of this work was to determine the phenotypic profile of bacteria of the Enterobacteriaceae family from the vaginal and preputial mucosa of stray dogs from a border region.

\section{MATERIALS AND METHODS}

\section{Local of study}

The study was conducted in two municipalities in the border region, one in the city of Umuarama in the northwestern region of the state of Paraná (PR), Brazil, which has a border of $110 \mathrm{~km}$ with Paraguay; and the other in the city of Dionísio Cerqueira, in the state of Santa Catarina (SC), Brazil, with a border of $5.8 \mathrm{~km}$ with Argentina.

The biological samples were collected from November 2019 to January 2020 from stray dogs of a non-governmental organization (NGO) that protects wandering animals in the state of Paraná (PR). In the state of Santa Catarina (SC) it was carried out in different houses of animal protectors that rescue these animals from the streets and stray them. In both places, the practice of adopting these animals is frequent.

These dogs, females and males, were healthy at the time of the physical examination, ranging from 6 months to 15 years old and weighing over $2 \mathrm{~kg}$.

The 88 biological samples were obtained after the animals were physically restrained with the help of their keepers and with the aid of muzzles, whenever necessary. Initially, the females and males were externally cleaned with a paper towel to collect the biological material in an appropriate way. After that, a swab was collected from the vaginal and preputial mucous of dogs using a sterile swab containing AMIES + activated charcoal medium $\left(\text { CopanTransystem }{ }^{\odot}\right)^{1}$. In females, the swab was introduced into the vagina performing rotating movements and in males the swab was inserted into the foreskin making circular movements.

After the collection, the biological materials were transported in Styrofoam boxes refrigerated with recycled ice, and sent to the Laboratory of Preventive Veterinary Medicine and Public Health, for sample processing. This laboratory is part of the Graduate Program in Animal Science with Emphasis on Bioactive Products, of the University of Paraná (UNIPAR).

\section{Bacterial isolation}

The swabs containing the vaginal and preputial samples were put into tubes containing $3.0 \mathrm{~mL}$ of Brain Heart Infusion (BHI) ${ }^{2}$ medium and incubated in an oven for $24 \mathrm{~h}$ at $37^{\circ} \mathrm{C}$. After this period, the cultures obtained were seeded by striation on plates containing MacConkey agar ${ }^{2}$ and kept in an incubator for 24 $\mathrm{h}$ at $37^{\circ} \mathrm{C}$ for colony isolation. The isolated colonies were pricked in $\mathrm{BHI}$ medium and then stored in $10 \%$ glycerol at $-20^{\circ} \mathrm{C}$ for conservation [11].

\section{Biochemical identification of isolates}

In order to identify the isolates, the samples kept at $-20^{\circ} \mathrm{C}$ were thawed, pricked in MacConkey agar medium, and incubated at $37^{\circ} \mathrm{C}$. After checking the purity of the strains and analyzing its macro and microscopic characteristics, the strains were classified as Gram-negative rods. The biochemical identification of bacteria belonging to the Enterobacteriaceae family was performed using a set of biochemical tests including the "Enterobacteria Kit" $\left(\mathrm{NewProv}^{\circledR}\right)^{3}$, according to the recommendations of the manufacturer [12]. 
Phenotypic assays of sensitivity to antimicrobials

The agar diffusion method was used to determine the bacterial resistance profile according to recommendations of the Brazilian Committee on Antimicrobial Susceptibility Testing [3]. The antimicrobials tested ${ }^{3}$ were amoxicillin + clavulanic acid $(30 \mu \mathrm{g})$, ampicillin $(10 \mu \mathrm{g})$, aztreonan $(30 \mu \mathrm{g})$, ceftazidime (30 $\mu \mathrm{g})$, cefalotin $(30 \mu \mathrm{g})$, cefoxitin $(30 \mu \mathrm{g})$, clindamycin $(2 \mu \mathrm{g})$, cloramphenicol $(30 \mu \mathrm{g})$, ceftriaxone $(30 \mu \mathrm{g})$, cefotaxime $(30 \mu \mathrm{g})$, enrofloxacin $(5 \mu \mathrm{g})$, gentamicin $(10 \mu \mathrm{g})$, metronidazole $(5 \mu \mathrm{g})$, norfloxacin $(10 \mu \mathrm{g})$, oxacillin $(1 \mu \mathrm{g})$, penicillin $(30 \mu \mathrm{g})$, sulfazotrim $(25$ $\mu \mathrm{g})$, tetracycline $(30 \mu \mathrm{g})$, and tobramycin $(10 \mu \mathrm{g})$. After incubation of the plate, the diameter of the inhibition zones around each drug for each microorganism was measured as sensitive, intermediate, and/or resistant.

\section{Bacterial resistance index}

The calculation of the multi-resistance index was based on the formula described by [13].

$$
\text { a/(b.c) }
$$

$\mathrm{a}=$ the sum of the number of antimicrobials to which the samples showed resistance.

$\mathrm{b}=$ number of antimicrobials tested.

$\mathrm{c}=$ number of samples.

The threshold to determine whether the samples were high risk or low risk samples was 0.200 , where those below 0.199 were considered low risk samples and those above 0.200 were considered high risk ones.

The multiresistance index of each sample was determined by the formula previously described [13]. $\mathrm{a} / \mathrm{b}$

$\mathrm{a}=$ number of antimicrobials against which the isolate was resistant.

$\mathrm{b}=$ number of antimicrobials tested.

\section{RESULTS}

Samples were collected from 70 animals, 60 $(85.7 \%)$ females and $10(14.2 \%)$ males. It was possible to isolate 88 samples, of which $36(40.9 \%)$ presented Gram-negative bacteria.

The complete identification was made in 29 $(80.5 \%)$ samples whereas in $7(19.4 \%)$ the identification was characterized as indeterminate. Escherichia coli was isolated from 13 isolates (44.8\%); followed by Obesumbacterium proteus in 8 (27.5\%); Enterobacter aerogenes and Enterobacter cloacae in 2 (6.8\%); and
Erwinia herbicola, Koserella trabulsii, Proteus mirabilis, and Serratia rubidaea (3.4\%) from 1 isolate.

Table 1 shows the total antimicrobial resistance, Table 2 shows the resistance profile of the vaginal and Table 3 shows the resistance profile of preputial bacterial isolates belonging to the Enterobacteriaceae family. The four antimicrobials that presented the highest bacterial resistance in the vaginal swabs were clindamycin $(100 \%)$, metronidazole $(100 \%)$, oxacillin $(100 \%)$, and penicillin (100\%). This was the same scenario observed in the preputial swabs, with the same percentages.

When the two studied sites were compared regarding bacterial resistance, the 5 antimicrobials that presented the highest bacterial resistance in Umuarama (PR x Paraguay) were clindamycin (100\%), metronidazole $(100 \%)$, oxacillin (100\%), penicillin $(100 \%)$, and amoxicillin + clavulanic acid $(80 \%)$, while in Dionisio Cerqueira (SC x Argentina) they were clindamycin $(100 \%)$, metronidazole $(100 \%)$, oxacillin $(100 \%)$, penicillin (100\%) and ampicillin (42.8\%).

The multiresistance index of vaginal isolates varied between 0.211 and 0.842 , while that of preputial isolates was 0.211 and 0.789 , showing that all isolates are outside the pre-stipulated threshold, being classified as a public health risk.

Table 1. Total resistance of antimicrobials of the vaginal and preputial mucous isolates from healthy stray dogs from two border regions (Paraná x Paraguay and Santa Catarina x Argentina), 2019-2020.

\begin{tabular}{ccc}
\hline Antimicrobial & Resistance & $\begin{array}{c}\text { Intermediate } \\
\text { Resistance }\end{array}$ \\
\hline Clindamycin & $100 \%$ & $*$ N/A \\
Metronidazole & $100 \%$ & $*$ N/A \\
Oxacillin & $100 \%$ & $*$ N/A \\
Penicillin & $100 \%$ & $*$ N/A \\
Ampicillin & $55.5 \%$ & $*$ N/A \\
Tetracycline & $36.1 \%$ & $27.7 \%$ \\
Cefalotin & $36.1 \%$ & $22.2 \%$ \\
Amoxicillin + Clavulanic Acid & $36.1 \%$ & $*$ N/A \\
Cefoxitin & $27.5 \%$ & $*$ N/A \\
Sulfazotrim & $25.0 \%$ & $8.3 \%$ \\
Cefotaxime & $19.4 \%$ & $0 \%$ \\
Ceftriaxone & $16.6 \%$ & $2.7 \%$ \\
Cloramphenicol & $11.1 \%$ & $*$ N/A \\
Aztreonan & $8.3 \%$ & $12.5 \%$ \\
Norfloxacin & $8.3 \%$ & $11.1 \%$ \\
Gentamicin & $8.3 \%$ & $2.7 \%$ \\
Ceftazidime & $8.3 \%$ & $0 \%$ \\
Tobramycin & $8.3 \%$ & $0 \%$ \\
Enrofloxacin & $5.5 \%$ & $13.8 \%$ \\
\hline
\end{tabular}

*N/A: Not applicable. antimicrobials that do not have a resistance zone diameter. 
Table 2. Antimicrobial resistance pattern of the vaginal mucous isolates from healthy stray dogs from two border regions (Paraná x Paraguay and Santa Catarina x Argentina), 2019-2020.

\begin{tabular}{|c|c|c|}
\hline Antimicrobial & Resistance & $\begin{array}{c}\text { Intermediate } \\
\text { Resistance }\end{array}$ \\
\hline Clindamycin & $100 \%$ & $* \mathrm{~N} / \mathrm{A}$ \\
\hline Metronidazole & $100 \%$ & $*$ N/A \\
\hline Oxacillin & $100 \%$ & $*$ N/A \\
\hline Penicillin & $100 \%$ & $*$ N/A \\
\hline Ampicillin & $60.6 \%$ & $*$ N/A \\
\hline Tetracycline & $36.3 \%$ & $30.3 \%$ \\
\hline Cefalotin & $36.3 \%$ & $24.2 \%$ \\
\hline Amoxicillin + Clavulanic Acid & $36.3 \%$ & $*$ N/A \\
\hline Cefoxitin & $27.7 \%$ & $*$ N/A \\
\hline Sulfazotrim & $24.2 \%$ & $9.1 \%$ \\
\hline Cefotaxime & $18.2 \%$ & $0 \%$ \\
\hline Ceftriaxone & $15.1 \%$ & $3.0 \%$ \\
\hline Cloramphenicol & $9.1 \%$ & $9.0 \%$ \\
\hline Aztreonan & $9.1 \%$ & $3.0 \%$ \\
\hline Norfloxacin & $9.1 \%$ & $0 \%$ \\
\hline Gentamicin & $9.0 \%$ & $0 \%$ \\
\hline Ceftazidime & $9.0 \%$ & $*$ N/A \\
\hline Tobramycin & $6.0 \%$ & $12.1 \%$ \\
\hline Enrofloxacin & $3.0 \%$ & $12.1 \%$ \\
\hline
\end{tabular}

*N/A: Not applicable. antimicrobials that do not have a resistance zone diameter.

\section{DISCUSSION}

Dogs and cats are the main pets found within family homes around the world, being treated as family members, sharing the same physical spaces. This has generated some concern, since these animals have already been incriminated as potential transmitters of different pathogens of unique health importance and there are also reports that tutors and their respective dogs may share the same antimicrobial resistance profile $[14,15]$.

The diseases found in the genital organs of male and female dogs have different degrees of morbidity and may be many times influenced by the environmental conditions, with microorganisms establishing a relationship of mutualism with the host, in which both benefit. However, when there is an imbalance in this relationship the animals become susceptible to infections caused by different microorganisms [16,17].

It is well known that the microorganisms that inhabit a certain environment or a specific part of the body are collectively called microbiomes. More specifically, some of them are bacteria that inhabit the reproductive mucous membranes (vaginal and preputial) of healthy dogs. Therefore, it was possible
Table 3. Antimicrobial resistance pattern of the preputial mucous isolates from healthy stray dogs from two border regions (Paraná x Paraguay and Santa Catarina x Argentina), 2019-2020.

\begin{tabular}{ccc}
\hline Antimicrobial & Resistance & $\begin{array}{c}\text { Intermediate } \\
\text { Resistance }\end{array}$ \\
\hline Clindamycin & $100 \%$ & $*$ N/A \\
Metronidazole & $100 \%$ & $*$ N/A \\
Oxacillin & $100 \%$ & $*$ N/A \\
Penicillin & $100 \%$ & $*$ N/A \\
Ampicillin & $33.0 \%$ & $33.3 \%$ \\
Tetracycline & $33.3 \%$ & $33.3 \%$ \\
Cefalotin & $33.3 \%$ & $0 \%$ \\
Amoxicillin + Clavulanic Acid & $33.3 \%$ & $0 \%$ \\
Cefoxitin & $33.3 \%$ & $0 \%$ \\
Sulfazotrim & $33.3 \%$ & $0 \%$ \\
Cefotaxime & $33.3 \%$ & $0 \%$ \\
Ceftriaxone & $33.3 \%$ & $*$ N/A \\
Cloramphenicol & $33.3 \%$ & $*$ N/A \\
Aztreonan & $33.3 \%$ & $*$ N/A \\
Norfloxacin & $33.3 \%$ & $*$ N/A \\
Gentamicin & $33.3 \%$ & $*$ N/A \\
Ceftazidime & $0 \%$ & $33.3 \%$ \\
Tobramycin & $0 \%$ & $0 \%$ \\
Enrofloxacin & $0 \%$ & $0 \%$ \\
\hline
\end{tabular}

*N/A: Not applicable. antimicrobials that do not have a resistance zone diameter.

to detect in this work eight different species of bacteria, all members of the family Enterobacteriaceae, with the most prevalent species being Escherichia coli (44.8\%). Several works [18-20] have also identified E. coli as the most prevalent bacteria identified in the vaginal and preputial mucosa of healthy dogs.

Although E. coli is regarded as a member of different microbiomes that is a commensal of different species of domestic animals, it is important to stress that this bacterial species presents sophisticated virulence mechanisms possibly responsible for different nosocomial infections as well as community infections in mankind and different species of animals [10,21,22,]. Evidence of this is a study conducted by Prescott et al. [21], which confirms the similarity between clinical isolates of this bacteria from the intestinal and urinary tracts of humans, dogs, and cats. This suggests that these species may be responsible for the transmission of intestinal and extra-intestinal pathogenic strains to humans, a fact which has been generating concern on public health.

Other 7 bacterial species were identified in this work as Obesumbacterium proteus (27.5\%), Enterobacter aerogenes and Enterobacter cloacae 
(6.8\%), Erwinia herbicola, Koserella trabulsii, Proteus mirabilis, and Serratia rubidaea (3.4\%), confirming the results of Quinn et al. [23], that have detected and identified the same microorganisms from bacterial isolates of clinical infections of animals and humans, and also from environmental samples. This suggests a connection of these bacterial species with different environments and different animal species, which is even more disturbing regarding public health, since most of the time dogs share the same spaces of their tutors, which would facilitate the transmission and interaction with potentially pathogenic microorganisms.

The phenotypic tests of sensitivity to different antimicrobials revealed a greater antimicrobial resistance to clindamycin, metronidazole, oxacillin, and penicillin. These isolates also presented resistance to other drugs, whereas the work of [24] detected resistance to amoxicillin + clavulanic acid, ampicillin, cephalotin, cefoxitin, and penicillin in bacterial isolates from canine pyometra.

These results demonstrated a varied profile of antimicrobial resistance that is most probably associated with the institution of clinical therapy in each study site, since the studies reported the possible continuous and irrational use of certain drugs. This exerts a selection pressure on the target pathogens and on the microorganisms of the normal microbiome, which might affect the human, animal, and environmental health. This may have deep consequences to the environment since it is where the complex relationships of microorganisms, genes conditioning resistance, and their respective hosts, take place [22,25-27]. Considering that the bacteria isolated in this study are microorganisms from vaginal and preputial membranes, a diversity of microorganisms may be affecting the behavior of the isolates evaluated in this study.

Another important situation is the MAR index, which showed that vaginal and preputial samples present a high risk to public health. This result is worrying when dealing with stray and asymptomatic dogs, since the behavioral particularities of canine species such as licking the body, licking the genitalia, sniffing the environment for territorial demarcation and, in some cases, coprophagy, may facilitate the transmission of pathogenic microorganisms and even disseminate genes of resistance to their keepers, other animals, and even to the environment. This illustrates the great relevance of this study for the unique health, mainly due to the frequent adoption of these animals.

Recent studies indicated that some bacteria, more specifically the enterobacteria E. coli, are often responsible for the emergence of pyometra in bitches, usually inhabiting the vagina, urinary tract, and intestinal tract of the animals $[28,29]$. They are also responsible for bacterial infections of the genitourinary tract affecting approximately 10 to $14 \%$ of male dogs [30-32]. Works focus on the identification and required use of antimicrobials only after the results of the phenotypic tests of susceptibility to these drugs. This prevents failures in the adopted therapy and worsening of the condition of the affected animal [33], besides enabling the transmission of resistance genes, as previously mentioned.

Border regions allow a high displacement of individuals and different species of animals, which can lead to possible unnoticed transmissions of microorganisms from one place to another between different species [34], since the interaction is intense and mediated by different factors, such as tourism, religion, and economy, among others. Due to this, the involved countries certainly have Gram-negative microorganisms from certain subgroups, based on bacterial species and patterns of susceptibility to specific antimicrobials, which may be exposed and disseminated to other sites, requiring therefore a special attention to borders.

\section{CONCLUSION}

The results of this work revealed the presence of 8 bacterial species belonging to the Enterobacteriaceae family. These results confirm that stray dogs may be regarded as potential reservoirs of pathogenic antimicrobial resistant microorganisms, allowing future potential problems of unique health due to the close coexistence of keepers with their dogs. New studies should be conducted to compare the clonal profile of the bacterial isolates from dogs with those from their keepers in order to assess the real situation.

Health education work should be conducted in border regions in order to raise awareness among the population involved in different situations that might favor the spread of microorganisms and their resistance genes, including the problems caused by the illegal sale and/or transportation of drugs, a situation that is very common at borders. 


\section{MANUFACTURERS}

${ }^{1}$ Copan Italia S.p.A. Brescia, Italy.

${ }^{2}$ Kasvi Importação e Distribuição de Produtos para Laboratórios Ltda. São José do Pinhais, PR, Brazil.

${ }^{3}$ Laborclin - Produtos para Laboratórios Ltda. Pinhais, PR, Brazil.

Funding. Financial support of a scholarship from CAPES Brazil.

Acknowledgements. To UNIPAR and Fundação Araucária CP 09/2016 Programa Institucional de Pesquisa Básica e Aplicada
- Protocol: 47661.491.48325.12122016 for the funding of this research, to PROSUP and PNPD, to the ONG and tutors of animals for the constant collaboration.

Ethical approval. The Research Ethics Committee Involving Animal Experimentation (CEPEEA) of the Universidade Paranaense (UNIPAR) under the Protocol 37765/2020 approved this project.

Declaration of interest. The authors report no conflicts of interest. The authors are the only ones responsible for the content and writing of this article.

\section{REFERENCES}

1 Almeida T.V. 2020. Fatores de risco para mastite bovina e avaliação fenotípica de resistência antimicrobiana. 96f. Goiânia, GO. Tese (Doutorado em Ciência Animal) - Escola de Veterinária e Zootecnia, Universidade Federal de Goiás.

2 Andrade A.C.S., Santos I.C., Barbosa L.D., Caetano I.C.S., Zaniolo M.M., Fonseca B.D., Martins L.A. \& Gonçalves D.D. 2019. Antimicrobial Resistance and Extended-Spectrum Beta-Lactamase Production in Enterobacteriaceae Isolates from Household Cats (Felis silvestris catus). Acta Scientiae Veterinariae. 47: 1630. DOI: 10.22456/1679-9216.90206

3 Banducci Júnior A. 2011. Turismo e fronteira: integração cultural e tensões identitárias na divisa do Brasil com o Paraguai. In: Pasos (La laguna, Espanha). Special Issue. 9(3): 7-18.

4 Becker G. 2015. Zoonoses transmitidas aos homens por animais de companhia - cães e gatos - e seus impactos na saúde pública. 67f. Medianeira, PR. Monografia (Especialista na Pós-Graduação em Gestão Ambiental em Municípios) - Programa de Especialização em Gestão Ambiental em Municípios, Universidade Tecnológica Federal do Paraná.

5 Brazilian Committee on Antimicrobial Susceptibility Testing (BrCAST). 2019. Tabelas de pontos de corte para interpretação de CIMs e diâmetros de halos. Comitê Brasileiro de Testes de Sensibilidade aos Antimicrobianos. Wayne: BrCAST, 71p.

6 Caliman M.C.W. 2010. Estudo de Vigilância Bacteriológica: Isolamento, Fatores de Virulência e Resistência Antimicrobiana de Cepas de Escherichia coli isoladas de Gatos Domésticos na Região de Ribeirão Preto. 113f. Jaboticabal, SP. Dissertação (Mestrado em Microbiologia Agropecuária) - Programa de Pós-Graduação da Faculdade de Ciências Agrárias e Veterinárias, Universidade Estadual Paulista.

7 Cháves R.S. 2019. Infección del tracto urinario en paciente Yorkshire Terrier en la clínica veterinaria Cayetano Heredia en el año 2016. 13f. Lima, Peru. Dissertação (Trabajo Académico para optar el Título de Especialista en Medicina de Animales de Compañía) - Facultad de Medicina Veterinaria y Zootecnia, Universidad Peruana.

8 Cooke C.L., Singer R.S., Jang S.S. \& Hirsh D.C. 2002. Enrofloxacin resistance in Escherichia coli isolated from dog with urinary tracts infections. Journal American Veterinary Association. 220(2): 190-192.

9 Foucher M. 2009. Regulamentar as fronteiras. In: Obsessão por Fronteiras. São Paulo: Radical Livros, pp.20-21

10 Groppetti D., Pecile A., Barbero C. \& Martino P.A. 2012. Vaginal bacterial flora and cytology in proestrous bitches: Role on fertility. Theriogenology. 77(8): 1549-1556. DOI: https://doi.org/10.1016/j.theriogenology.2011.11.022

11 Guardabassi L., Schwarz S. \& Lloyd D.H. 2004. Pet animals as reservoirs of antimicrobial-resistant bacteria. Journal of Antimicrobial Chemotherapy. 54(2): 321-332.

12 Hogenová H.T., Stepanková R., Hudcovic T., Tucková L., Cukrowska B., Rája L.Z., Hana K., Pavel R., Jirina B., Sokol D., Funda D.P., Borovská D., Reháková Z., Sinkora J., Hofman J., Drastich P. \& Kokesová A. 2004. Commensal bacteria (normal microflora), mucosal immunity and chronic inflammatory and autoimmune diseases. Immunology Letters. 93(2-3): 97-108. DOI: 10.1016/ 2004.02.005.

13 Krumperman P.H. 1983. Multiple antibiotic resistance indexing of Escherichia coli to identify hihg-risk sources of fecal contamination of foods. Applied Environmental Microbiology. 46(1): 165-170.

14 Linhares I.M., Giraldo P.C. \& Baracat E.C. 2010. Novos conhecimentos sobre a flora bacteriana vaginal. Revista da Associação Médica Brasileira. 56(3): 370-374.

15 Lourenço B.L.P. 2017. Análise da estrutura populacional de Escherichia coli em amostras de origem fecal e vaginal de cadelas. 70f. Lisboa, Portugal. Dissertação (Mestrado Integrado em Medicina Veterinária), Universidade de Lisboa. 
16 Matuzaiki C.C., Silva B.B.M, Sarrano B.E.D., Paié N.B., Cabral P.S.B., Dorneles I.C. \& Otutumi L.K. 2019. Os proprietários de cães podem compartilhar do mesmo perfil de resistência que seus cães? In: Anais do III Concivet (Umuarama, Brazil). pp.91-92.

17 Menezes C.C.F. 2005. A importância do médico veterinário na saúde pública. 54f. Fortaleza, CE. Monografia (Graduação em Medicina Veterinária), Universidade Estadual do Ceará.

18 Oliveira F.S., Paz L.N., Mota T.M., Oriá A.P., Silva M.C.A. \& Pinna M.H. 2016. Perfil de resistência de isolados de Escherichia coli a partir de piometra canina. Ciência Animal Brasileira. 17(4): 615-621. DOI: 10.1590/10896891v17i438817

19 Pereira A.R.V.C. 2011. Antibioresistência em Piometra Canina. 65f. Lisboa, Portugal. Dissertação (Mestrado integrado em Medicina Veterinária), Universidade Lusófona de Humanidades e Tecnologias.

20 Petreigne C. 2017. Diagnóstico de infección urinaria en canino macho. 25f. Tandil, Argentina. Tese (Orientação em Saúde Animal), Facultad de Ciencias Veterinarias.

21 Prescott J.F., Hanna W.J.B., Reid-Smith R. \& Drost K. 2002. Antimicrobial drug use and resistance in dogs. $\mathrm{Ca}$ nadian Veterinary Journal. 43(2): 107-116.

22 Previato P.F.G., Pinto Neto A., Werner P.R., Acco A., Mota M.F., Silva A.V. \& Fonseca J.F. 2005. Alterações morfológicas nos órgãos genitais de cães e gatos provenientes de Vilas Rurais da região de Umuarama-PR. Arquivos de Ciências Veterinárias e Zoologia da UNIPAR. 8(2): 105-110.

23 Quinn P.J., Carter M.E., Markey B. \& Carter G.R. 1994. Enterobacteriaceae. In: Clinical Veterinary Microbiology. London: Wolfe Publishing, pp.209-236.

24 Quinn P.J., Markey B., Carter M.E., Donnell W.J. \& Leonard F.C. 2005. Microbiologia Veterinária e Doenças Infecciosas. Porto Alegre: Artmed, pp.115-130.

25 Radke V. 2019. Antimicrobial Resistance. Journal of Environmental Health. 81(8): p.6+.

26 Rodríguez M.R. 2007. Simbiosis entre aves y bacterias. Propiedades y modo de adquisición de la microbiota intestinal de críalos y urracas, y de la existente en la glândula uropigial de abubillas. 227f. Granada, Espanha. Tese (Doctorado en Ciencias Biológicas), Universidad de Granada.

27 Round J.L. \& Mazmanian S.K. 2009. The gut microbiota shapes intestinal immune responses during health and disease. Nature Reviews Immunology. 9: 313-323. DOI: https://doi.org/10.1038/nri2515

28 Santana T.C.F.S., Pereira E.M.M., Monteiro S.G., Carmo M.S., Turri R.J.G. \& Figueiredo P.M.S. 2012. Prevalência e resistência bacteriana aos agentes antimicrobianos de primeira escolhas nas infecções do trato urinário no município de São Luís-MA. Revista de Patologia Tropical. 41(4): 409-418.

29 Singh B.R., Sinha D.K., Vinodh K.O.R., Abhijit M.P., Ujjwal K. \& Vinod K.G. 2019. Comparative antimicrobial activity of Pogostemon cablin (patchouli) essential oil (PEO) and conventional antimicrobials against clinically important microbes. World Journal of Pharmaceutical Sciences. 7(8): 47-65.

30 Solano C.N., Cahua U.J., Gonzales Z.A. \& Gavidia C.C. 2019. Frequência de piometra em cadelas da Clínica de Animales Minores da Faculdade de Medicina Veterinária da Universidade Nacional Prefeito de San Marcos no período 2009-2013. Jornal de Pesquisa Veterinária do Peru. 30(1): 512-516. DOI: https://doi.org/10.15381/rivep.v30i1.15665

31 Vasques G.M.B., Romani I., Mattosinho R.O., Fiorato C.A., Almeida L.M. \& Machado M.A. 2018. Principais exames diagnósticos nas doenças prostáticas em cães: Revisão. Revista de Ciência Veterinária e Saúde Pública. 5(2): 231-250. DOI: http://dx.doi.org/10.4025/revcivet.v5i2.41718

32 Volpato R., Ramos R.S., Magalhães L.C.O., Lopes M.D. \& Sousa D.B. 2010. Afecções do pênis e prepúcio de cães - Revisão de literatura. Veterinária e Zootecnia. 17(3): 312-323.

33 Wanderley M.C.P. 2015. Ocorrência de Escherichia coli resistente a antimicrobianos em diferentes sítios corporais em uma população diversa de gatos saudáveis. 118f. Jaboticabal, SP. Tese (Doutorado em Microbiologia Aplicada) Programa de Pós-graduação da Faculdade de Ciências Agrárias e Veterinárias, Universidade Estadual Paulista.

34 World Health Organization (WHO). 2018. Antimicrobial Resistance. Global Report on Surveillance. Geneva: World Health Organization, 265p. 